\title{
Native to place: Grass, Soil, Hope by Courtney White
}

Book review by Philip A. Loring *

University of Saskatchewan

\section{Grass, Soil, Hope: A Journey Through Carbon Country, by Courtney White}

White, C. (2014). Grass, soil, hope: A journey through Carbon Country. White River Junction, Vermont: Chelsea Green Publishing. Available as

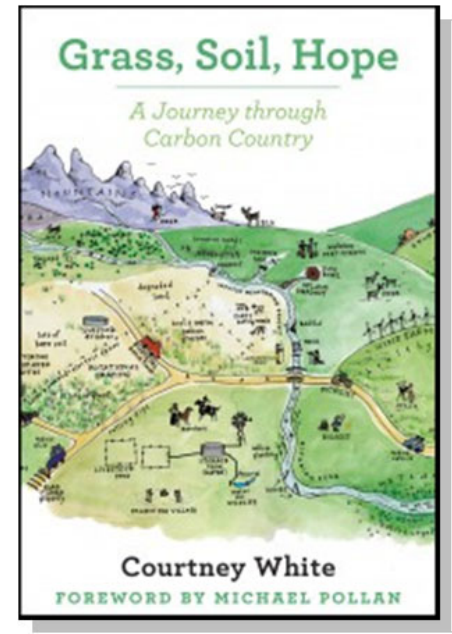
paperback; 272 pages. Publisher's website: http://media.chelseagreen.com/grass-soil-hope/

Published online October 17, 2014

Citation: Loring, P. A. (2014). Native to place: Grass, Soil, Hope by Courtney White [Book review]. Journal of Agriculture, Food Systems, and Community Development, 5(1), 189-191. http://dx.doi.org/10.5304/jafscd.2014.051.002

Copyright (C) 2014 by New Leaf Associates, Inc.

$\mathrm{I}^{\mathrm{n}}$ n Grass, Soil, Hope (2014, Chelsea Green), archaeologist-turned-activist-turned-cattle rancher (and now writer) Courtney White recounts a personal journey to discover "on-the-groundsolutions to the rising challenges of the $21^{\text {st }}$ century" (Introduction, p. XX). Throughout the book he circles two common themes — the role of carbon in both creating and solving environmental problems, and paradigm change - and uses these themes to stitch together stories of ranching, organic farming, wetlands restoration, and beaver conservation, among others. Individually the stories are interesting forays into creativity and innovation at the local scale. Taken together,

* Philip A. Loring is an assistant professor in the School of Environment and Sustainability at the University of Saskatchewan. He is a human ecologist with training in anthropology and ecology, and research interests in food systems and security, fisheries, and environmental justice. He can be contacted at phil.loring@usask.ca and followed on Twitter:@paloring. however, they suggest a compelling and hopeful thesis: that sustainability is not merely about learning to minimize human impacts, but about learning to reorganize our actions such that they become important to the rest of the natural community, fostering biodiversity and promoting healthy ecosystem structure and function.

Carbon, according to White, is a common thread that cuts across many, if not all, contemporary environmental problems. Focusing on how people in a variety of ecological systems are experimenting with managing carbon, White builds the case that sustainability requires a mosaic of interlocking, place-based solutions. But whereas many authors implicate and even vilify carbon with respect to environmental challenges (think emissions and global warming), White is more pragmatic; he argues for consideration of carbon as a tool that can "be used for good or evil depending on one's goals" (p. 13).

This conciliatory attitude toward carbon 
underlies what is arguably the most important theme in the book: paradigm change. White urges the reader to abandon what he describes as the fatalistic and antagonistic philosophy of human nature that many environmentalists seem to embrace: that we are fundamentally destroyers of the natural world and that meeting our own needs will necessarily come at its expense. White contends that this perspective limits our options, locking us into what he calls "scarcity thinking," a mindset that he argues will always steer us toward thinking about sustainability as a matter of tradeoffs and enforcement of limits to human consumption. The point he seems to be making is that the metaphor of limits, while a fundamental tenet of sustainability, make for a poor vision to guide our common future.

With this line of thought, White bucks a mountain of $20^{\text {th }}$ century environmental philosophy (everything from Garrett Hardin's “Tragedy of the Commons" to Paul and Anne Erlich's I=PAT equation). Yet he is not alone in this argument; other writers such as Wes Jackson, Daniel Quinn, Elinor Ostrom, Nathan Sayre, and Paul

Rosenzweig all in various ways encourage a more optimistic (and empirically justifiable) philosophy on human nature. White joins these writers in asking readers to reexamine their assumptions about the roles that people can play in ecosystems, and encourages them to look instead to matters of technology, culture, and social inequities for explanations of ecological degradation.

Surveys of sustainability case studies such as this have become common fare in environmental reading, following works by Michael Pollan (who writes the foreword), Dan Daggett, and many others. Some have critiqued this approach as "cherry picking," in that they put too much emphasis on unique systems at the local level while ignoring whether these solutions are "scalable." While common, this criticism is inherently fallacious - it's guilty of "moving the goal post" in that it evaluates locally scaled solutions based on their ability to do something they do not purport to do: solve regional and global problems. Yet White surprises here by taking on the scaling question anyway, suggesting that carbon management is the common feature necessary in all local systems for making such a mosaic approach work.

With this book White also takes on the currently divisive question of resilience, exploring what it does and doesn't offer as a design principle for sustainability. He aptly chooses the case of New Orleans and Hurricane Katrina to couch his discussion, which is an exemplar of both the good and bad sides of resilience. He describes the city as a place that "bounced back... but just barely and only with a great deal of expense and suffering" ( $p$. 105). These words are as succinct a summary of resilience in the context of social systems as I have ever encountered, and they are illustrative of the problem with resilience: it is important, necessary even, but focuses too much on endurance and recovery to provide a vision for a better future (Loring 2013; Yanarella \& Levine 2014). Resilience is advertised by many as a source of science-based best practices for sustainability, and in some cases as a preferable replacement for sustainability altogether (Benson \& Craig 2014); yet, in White's words, we need to think about life as "more than resilience, more than [mere] survival and bouncing back" (p. 129).

White's book is not without its shortcomings, of course. His attempt to keep the tone entirely conversational and his overuse of rhetorical questions to drive the narrative will surely frustrate some readers. He also makes some strange segues that, while interesting, may distract readers from the thesis he is developing throughout the chapters. Even Homer Simpson makes an appearance in White's narrative. This is particularly unfortunate (the segues, not Homer Simpson), because White is introducing a lot of important ideas here - ideas that cumulatively provide a scaffolding for a new way of thinking about sustainability challenges. Indeed, with his comments on life force and life as art and embracing change, White is flirting with a moral environmental philosophy that is reminiscent of the Tao, though he covers too much ground in too few words for this contribution to shine through.

Whether you are a newcomer to literature on small-scale sustainability or a scholar working in the areas of human or landscape ecology or ecosystem services, this book deserves a read. It is not revolutionary, but it does add a valuable and 
unique new voice to the discussion. It also leaves the reader with some lingering ideas about recon-

ciling ourselves in the natural world, and hope that it is indeed possible to, as Wes Jackson called it, "become native to place."

\section{References}

Benson, M. H., \& Crain, R. K. (2014). The end of sustainability. Society \& Natural Resources, 27(7), 777-782. http://dx.doi.org/10.1080/08941920. 2014.901467

Loring, P. A. (2013). Are we acquiescing to climate change? Social and environmental justice considerations for a changing Arctic. In F. J.

Mueter, D. M. S. Dickson, H. P. Huntington, J. R. Irvine, E. A. Logerwell, S. A. MacLean, L. T.

Quakenbush, \& C. Rosa (Eds.), Responses of Arctic marine ecosystems to climate change (pp. 1-11). Fairbanks, Alaska: Alaska Sea Grant, University of Alaska Fairbanks. https://seagrant.uaf.edu/ bookstore/pubs/AK-SG-13-03.html

Yanarella, E. J., \& Levine, R. S. (2014). From sustainability to resilience: Advance or retreat? Sustainability: The Journal of Record, 7(4), 197-208. http://dx.doi.org/10.1089/SUS.2014.9782 